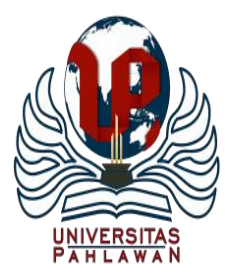

Edukatif : Jurnal Ilmu Pendidikan Volume 3 Nomor 1 Tahun 2021 Halm 180-187

EDUKATIF: JURNAL ILMU PENDIDIKAN

Research \& Learning in Education

https://edukatif.org/index.php/edukatif/index

\title{
Penerapan Model Pembelajaran Blanded Learning dalam Meningkatkan Hasil Belajar Siswa Sekolah Menengah Kejuruan
}

\author{
Marsel Nande ${ }^{1 凶}$, Wati Ahmad Irman ${ }^{2}$ \\ Universitas Flores, Indonesia ${ }^{1,2}$ \\ E-mail : $\underline{\text { marselnande@gmail.com }}^{1} \underline{\text { watiirman @ gmail.com }}^{2}$
}

\begin{abstract}
Abstrak
Tujuan penelitian ini yaitu untuk meningkatkan hasil belajar siswa pada mata pelajaran Buku Besar kelas XA Akuntansi SMK Negeri 1 Ende melalui penerapan blended learning. Jenis penelitian yang digunakan dalam penelitian ini adalah penelitian tindakan kelas (PTK). Subjek penelitian ini adalah siswa kelas XA SMK Negeri 1 Ende sebanyak 32 orang. Adapun teknik pengumpulan data yang digunakan dalam penelitian ini adalah: (1) tes, (2) observasi, (3) dokumentasi. Data penelitian yang diperoleh dianalisis secara deskriptif menggunakan statistika deskriptif sederhana. Berdasarkan temuan bahwa pembelajaran Akuntansi Dasar Bahan ajar Buku Besar telah terlaksana dengan baik. Pada ranah kognitif sebesar 18,64\% dari siklus I ke siklus II. Pada ranah afektif sebesar 58,90\% dari siklus I ke siklus II. Sedangkan ranah psikomotorik sebesar $27,72 \%$ dari siklus I ke siklus II.
\end{abstract}

Kata Kunci: Buku besar, blended learning, hasil belajar.

\section{Abstract}

The purpose of this study, namely to improve student learning outcomes in the subject of ledger class XA Accounting at SMK Negeri 1 Ende through the application of blended learning. This type of research used in this research is classroom action research (CAR). The subjecs of this research were 32 students of class XA SMK Negeri 1 Ende. At the same time, the data collection techniques used in this study were: (1) testing, (2) observation, (3) documentation. The research data obtained were analyzed descriptively using simple descriptive statistics. Based on the findings of researchers that learning Basic Accounting, Ledger teaching materials have been done well. In the cognitive domain, it was $18.64 \%$ from cycle I to cycle II. In the affective domain, it was $58.90 \%$ from cycle I to cycle II. Meanwhile, the psychomotor domain was $27.72 \%$ from cycle I to cycle II.

Keywords: ledger, blended learning, learning outcomes.

Copyright (c) 2021 Marsel Nande, Wati Ahmad Irman

$\triangle$ Corresponding author

Email : marselnande@gmail.com

DOI : https://doi.org/10.31004/edukatif.v3i1.240
ISSN 2656-8063 (Media Cetak)

ISSN 2656-8071 (Media Online) 
181 Penerapan Model Pembelajaran Blanded Learning dalam Meningkatkan Hasil Belajar Siswa Sekolah Menengah Kejuruan - Marsel Nande, Wati Ahmad Irman

DOI : https://doi.org/10.31004/edukatif.v3i1.240

\section{PENDAHULUAN}

Buku besar memiliki kedudukan yang sangat penting dalam siklus akuntansi (Siregar, 2019), oleh karenanya materi buku besar merupakan salah satu materi yang dipelajari oleh siswa Kelas X SMK Jurusan Akuntansi. Penguasaan kompetensi dalam mengelola buku besar merupakan jembatan siswa SMK jurusan Akuntansi untuk menguasai siklus akuntansi (Wardani, 2015), sehingga siswa memiliki kemampuan, kematangan dan kesiapan untuk masuk ke dalam dunia kerja (Budiarti \& Supraptono, 2015).

Berbagai penelitian menunjukkan bahwa materi buku besar sangat sulit dipahami oleh para siswa kelas X SMK (Chesaria, Adi \& Muchsini, 2015; Susanto \& Ulfa, 2016). Kesulitan memahami materi buku besar dipengaruhi oleh banyak faktor diantaranya adalah antusias siswa untuk belajar sangat kurang, siswa cenderung menerima apa saja yang disampaikan oleh guru, dan enggan mengemukakan pertanyaan maupun pendapat (Budiarti \& Supraptono, 2015). Minat, disiplin, dan dan cara belajar juga dapat mempengaruhi hasil belajar akuntansi siswa (Wiwiseno, 2011). Kesulitan dan kendala yang sama juga dialami oleh para siswa kelas XA Akuntansi SMK Negeri 1 Ende.

Berdasarkan observasi awal dan wawancara dengan guru sebelum melaksanakan penelitian ini, ditemukan masalah utama yang dihadapi adalah proses pembelajaran hanya dilakukan di kelas tanpa ada interaksi tindak lanjut secara berkesinambungan ketika siswa belajar di luar sekolah. Banyak siswa yang tidak melakukan latihan mandiri di rumah karena untuk menguasai materi siklus akuntansi khususnya buku besar diperlukan latihan-latihan atau praktik secara kontinu. Latihan mandiri ini juga butuh pengawasan dan pengarahan dari guru karena buku besar seperti materi lainnya menekankan pada keterampilan sehingga proses latihan dan diskusi harus terus dilakukan antara siswa dan siswa, maupun siswa dan guru. Selanjutnya, berdasarkan wawancara awal dengan siswa, banyak yang mengeluhkan bahwa metode atau model pembelajaran yang diterapkan oleh guru bersifat monoton dan seringkali menyebabkan peserta didik menjadi bosan dalam mengikuti kegiatan belajar mengajar (KBM). Siswa juga merasakan kurangnya waktu untuk berinteraksi serta saling bertukar pendapat diluar dari jam tatap muka yang ditentukan oleh sekolah.

Kurangnya latihan dengan pengarahan guru seperti ini yang menyebabkan saat ini banyak hasil belajar peserta didik belum optimal. Oleh karenanya masalah ini perlu diatasi dengan memanfaatkan teknologi guna mendukung pembelajaran. Dalam hal ini semestinya para guru memanfaatkan teknologi informasi dan komunikasi yang kian berkembang saat ini dengan menciptakan media dan model pembelajaran yang lebih menarik dengan sentuhan teknologi informasi dan komunikasi (TIK). Apalagi saat ini, siswa SMK yang masuk dalam golongan generasi milenial terbiasa dengan hal yang simple dan praktis sehingga di bidang pendidikan, dengan kemajuan teknologi kini semakin bermunculan berbagai pembelajaran berbasis internet (Hignasari \& Supriadi, 2020). Penerapan pembelajaran yang dikombinasikan media pembelajaran dengan memanfaatkan teknologi di luar jam pelajaran secara online namun tidak terlepas dari pembelajaran tatap muka atau lebih dikenal dengan istilah face-to-face (Abdullah, 2018).

Media pembelajaran merupakan salah satu faktor yang turut mempengaruhi keberhasilan pendidikan. Penggunaan media yang tepat akan turut menentukan tingkat keberhasilan proses pembelajaran (Abdullah, 2017). Di era kemajuan teknologi pada saat ini, media yang dapat digunakan sangatlah banyak seperti media cetak, media elektornik, maupun media pendidikan yang memang dipersiapkan untuk memudahkan pembelajaran. Media pembelajaran dengan sentuhan teknologi informasi dan komunikasi munculah sebuah konsep yang dikenal dengan konsep E-Learning (Hanum, 2013; Yazdi, 2012). E-Learning juga merupakan suatu konsep atau konsep pendidikan yang memanfaatkan teknologi informasi dalam proses belajar mengajar (Seto et al., 2020).

E-Learning merupakan sebuah model pembelajaran yang memiliki ciri dapat digunakan siapa saja (everyone), dimana saja (everywhere), dan kapanpun (everytime) saja . E-Learning menitik beratkan pada 
182 Penerapan Model Pembelajaran Blanded Learning dalam Meningkatkan Hasil Belajar Siswa Sekolah Menengah Kejuruan - Marsel Nande, Wati Ahmad Irman

DOI : https://doi.org/10.31004/edukatif.v3i1.240

keefisienan sebuah proses belajar mengajar. E-learning merupakan proses pembelajaran yang ada dibuat dalam format digital melalui peralatan elektronik dengan tujuan memperluas akses terhadap pendidikan publik, sehingga belajar modul bisa diakses mudah tanpa ruang dan waktu dibatasi, interaktif dan efektif (Seto et al., 2020). Penggunaan model pembelajaran E-Learning mempermudah peserta didik untuk mengakses bahan pelajaran, berdiskusi dengan teman, serta saling bertanya atau bertukar pendapat dengan pengajar (guru) dimana dan kapan pun saja. Selain itu, pengajar juga dapat menyiapkan referensi melalui internet yang dapat diakses sendiri oleh peserta didik sehingga dapat menambah wawasannya, dan lebih memudahkan guru untuk melakukan pengawasan dalam penguasaan materi pelajaran oleh peserta didik. Mengabungkan model pembelajaran seperti diatas sering disebut dengan istilah Blended Learning dimana model pembelajarannya yaitu mengabungkan antara pembelajaran secara tatap muka dengan kombinasi daring/daring kombinasi (Muzakkir et al., 2018). Husamah (2014) menyampaikan pendapatnya bahwa blended learnig memiliki kelebihan dalam aksebilitas pembelajaran sehingga nantinya berdampak pada kemudahan siswa dalam mengakses materi pelajaran sehingga peserta didik dapat meningkatkan hasil belajarnya.

SMK Negeri 1 Ende merupakan salah satu sekolah kejuruan yang ada di Kabupaten Ende yang memiliki sarana dan prasarana yang dapat dikatakan sudah cukup baik untuk bisa menerapkan konsep pembelajaran seperti Blended Learning yang membutuhkan akses internet. Namun pada kenyataannya, guru sering tidak memanfaatkan fasilitas sekolah berupa internet untuk menunjang wawasan peserta didik yang merupakan Generasi $Z$ yang familiar dengan perubahan paling besar di abad ini dengan web, internet, ponsel pintar, dan laptop (Lestiyani, 2020).

Menurut Husamah (2014) dari berbagai kebaikan yang ditawarkan blended learning, dapat meningkatkan hasil belajar siswa karena siswa dapat melakukan proses pembelajaran dengan leluasa, dengan akses materi yang mudah melalui online serta mudah untuk berkomunikasi dan berdiskusi baik dengan guru maupun teman yang dilakukan dimana saja dengan media internet. Hasil-hasil penelitian seperti yang telah dilakukan oleh Dziuban et al (2006) juga menunjukkan bahwa blended learning memiliki potensi untuk meningkatkan hasil belajar dan juga menurunkan tingkat putus sekolah. Selain itu juga blended learning dianggap dapat menjadi sebuah model pembelajaran yang lebih baik dari pada pembelajaran yang bersifat hanya tatap muka (face to face).

Model Pembelajaran Blended Learning diharapkan dapat mengurangi kelemahan dari pembelajaran tatap muka dan juga pembelajaran E-Learning. Model pembelajaran ini dapat menggunakan media sosial yang sering disalahgunakan oleh peserta didik untuk hal-hal yang cenderung bersifat negatif. Namun dengan kehadiran model pembelajaran Blended Learning diharapkan membawa dampak positif dalam meningkatkan hasil belajar siswa. Penggunaan media sosial ini akan membantu guru dan peserta didik untuk melakukan komunikasi sekaligus memberikan penjelasan serta menjawab pertanyaan siswa serta dapat memberikan materi pelajaran, tugas, dan latihan kepada peserta didik.

Penelitian ini berupaya untuk menggunakan model pembelajaran Blended Learning sebagai jalan keluar untuk meningkatkan hasil belajar siswa Kelas XA Akuntansi SMK Negeri 1 Ende Tahun Ajaran 2018/2019 pada materi ajar Buku Besar.

\section{METODE PENELITIAN}

Penelitian ini merupakan jenis Penelitian Tindakan Kelas. Penelitian ini berfokus pada usaha melihat dan memahami kesenjangan antara keadaan nyata dengan keadaan yang diharapkan selanjutnya memecahkan masalah yang pembelajaran yang ditemukan (Rahim \& Dwiprabowo, 2020). Penelitian ini dilaksanakan dalam dua siklus. Setiap siklus terdiri dari tahap perencanaan, tindakan dan refleksi. Penelitian ini dilaksanakan di 
183 Penerapan Model Pembelajaran Blanded Learning dalam Meningkatkan Hasil Belajar Siswa Sekolah Menengah Kejuruan - Marsel Nande, Wati Ahmad Irman

DOI : https://doi.org/10.31004/edukatif.v3i1.240

SMK Negeri 1 Ende Kecamatan Ende Timur Kabupaten Ende. Subjek penelitian ini adalah semua siswa kelas X A Akuntansi SMK Negeri 1 Ende Tahun Pelajaran 2019/2020 sebanyak 32 siswa.

Pengumpulan data dilakukan dengan cara observasi dan dokumentasi dan tes hasil belajar pada setiap siklus penelitian tindakan. Studi dokumen dilakukan dengan mengumpulkan data berupa perangkat pembelajaran (Silabus, RPP, dan Bahan Ajar) dan hasil belajar siswa pada kompetensi dasar sebelum dilakukan penelitian yang berguna untuk mempersiapkan materi pembelajaran, soal latihan dan tes hasil belajar pada Siklus I. Selanjutnya berdasarkan hasil refleksi pelaksanaan Siklus I, dilakukan perencanaan perbaikan untuk pelaksanaan Siklus II.

Data yang diperoleh dari lembar observasi dan juga hasil tes belajar merupakan data kuantitatif yang menunjukkan penilaian atas hasil belajar siswa dalam tiga ranah yaitu ranah kognitif (pendidikan), ranah afektif (sikap), dan juga ranah psikomotorik (keterampilan). Teknik pengolahan data kuantitatif menggunakan statistika deskriptif sederhana yang berupa angka-angka seperti nilai rata-rata dan perhitungan ketuntasan dari ketiga ranah. Sedangkan analisis data kualitatif digunakan untuk mendeskripsikan data yang berasal dari catatan lapangan berupa seluruh rangkaian observasi pembelajaran dimana data yang diperoleh berbentuk data kualitatif. Data kualitatif digunakan untuk proses refleksi guna merencanakan keberlanjutan atau selesainya pelaksanaan tindakan.

\section{HASIL DAN PEMBAHASAN PENELITIAN}

Penelitian ini menerapkan metode pembelajaran yang inovatif yaitu Model Pembelajaran Blended Learning untuk meningkatkan hasil belajar siswa pada ranah kognitif, afektif, maupun psikomotor. Pelaksanaan pembelajaran dengan menggunakan Model Pembelajaran Blended Learning merupakan gabungan dari model pembelajaran konvensional dengan model pembelajaran yang menggunakan teknologi informasi dan komunikasi sehingga dapat memberikan dampak positif bagi pembelajaran di kelas maupun dirumah. Penggabungan kedua model pembelajaran ini dapat dikatakan Blended Learning apabila proporsi penggunaan media online atau teknologi informasi dan komunikasi dari keseluruhan waktu pembelajaran.

Pelaksanaan model pembelajaran Blended Learning menggunakan kombinasi model pembelajaran konvensional atau tatap muka dan menggunakan media online. Tahap pelaksanaan Model pembelajaran Blended Learning yang pertama mempersiapkan media online yang digunakan untuk mengunggah materi, tugas, mengumpulkan tugas, serta media bertukar informasi atau tanya jawab, baik antar guru dan siswa dan lainnya. Media online yang dipilih adalah facebook group, karena semua siswa yang terdapat di kelas X A Akuntansi memiliki akun facebook sehingga mempermudah siswa untuk mengakses media online tersebut. Setelah media online selesai dibuat, semua siswa dimasukkan sebagai anggota facebook group tersebut.

Tahap selanjutnya adalah membuat materi yang akan diunggah di dalam media online. Setelah persiapan pertama selesai, tahap selanjutnya adalah persiapan yang kedua yaitu mempersiapkan pembelajran tatap muka yang berlangsung di dalam kelas. Pembelajaran di dalam kelas yang akan dilakukan meliputi pendahuluan, pre-test dan post-test, presentasi oleh guru, pemberian tugas yang diunduh di media online, serta penutup.

Hasil belajar merupakan hasil yang diperoleh siswa setelah mengikuti serangkaian proses belajar yang terdiri dari ranah kognitif, afektif dan psikomotorik (Prama Deswita, 2015). Dalam konteks penelitian ini, keberhasilan belajar ranah kognitif siswa terwujud apabila siswa telah mampu menguasai materi yang dipelajari. Hal tersebut dapat dilihat dari hasil evaluasi yang dilakukan dengan tes tertulis pada setiap ahkir siklus. Siswa dapat dikatakan telah mencapai kriteri ketuntasan belajar apabila memperoleh $\geq 75$, sesuai dengan kriteria ketuntasan minimal yang telah ditentukan pihak sekolah. 
184 Penerapan Model Pembelajaran Blanded Learning dalam Meningkatkan Hasil Belajar Siswa Sekolah Menengah Kejuruan - Marsel Nande, Wati Ahmad Irman

DOI : https://doi.org/10.31004/edukatif.v3i1.240

\section{a. Peningkatan Hasil Belajar Kognitif}

Hasil tindakan menunjukkan bahwa telah terjadi peningkatan hasil belajar siswa pada ranah kognitif antara siklus I dan siklus II. Pada siklus I nilai rata-rata kognitif siswa satu kelas sebesar 77,97 dengan jumlah siswa yang mencapai ketuntasan minimal sebanyak 26 orang atau sebesar $81,24 \%$ dari jumlah siswa dalam satu kelas. Kemudian pada siklus II, nilai rata-rata kognitif siswa meningkat menjadi 92,5 dengan seluruh siswa yang mencapai ketuntasan minimal atau sama dengan $100 \%$ dari siswa yang mengikuti kegiatan pembelajaran dikelas. Berikut disajikan Tabel peningkatan hasil belajar siswa ranah kognitif siklus I dan siklus II.

Tabel 1. Hasil Belajar Kognitif Siswa Siklus I dan II

\begin{tabular}{|c|c|c|c|c|c|}
\hline \multirow{2}{*}{ Kategori } & \multirow{2}{*}{ Nilai } & \multicolumn{2}{|r|}{ Siklus I } & \multicolumn{2}{|r|}{ Siklus II } \\
\hline & & Frekuensi & Persentase & Frekuensi & Presentase \\
\hline \multirow{2}{*}{$\begin{array}{c}\text { Sangat } \\
\text { Baik }\end{array}$} & \multirow[t]{2}{*}{$85-100$} & \multirow[t]{2}{*}{5} & $=5 / 32 \times 100 \%$ & \multirow[t]{2}{*}{30} & $=30 / 32 \times 100 \%$ \\
\hline & & & $=15,62 \%$ & & $=93,75 \%$ \\
\hline \multirow[t]{2}{*}{ Baik } & \multirow[t]{2}{*}{$75-84$} & \multirow[t]{2}{*}{21} & $=21 / 32 \times 100 \%$ & \multirow[t]{2}{*}{2} & $=2 / 32 \times 100 \%$ \\
\hline & & & $=65,62 \%$ & & $=6,25 \%$ \\
\hline \multirow[t]{2}{*}{ Cukup } & \multirow[t]{2}{*}{$65-74$} & \multirow[t]{2}{*}{3} & $=3 / 32 \times 100 \%$ & \multirow[t]{2}{*}{0} & $=0 / 32 \times 100 \%$ \\
\hline & & & $=9,38 \%$ & & $=0 \%$ \\
\hline \multirow[t]{2}{*}{ Kurang } & \multirow[t]{2}{*}{$55-64$} & \multirow[t]{2}{*}{2} & $=2 / 32 \times 100 \%$ & \multirow[t]{2}{*}{0} & $=0 / 32 \times 100 \%$ \\
\hline & & & $=6,25 \%$ & & $=0 \%$ \\
\hline \multirow[t]{2}{*}{ Gagal } & \multirow[t]{2}{*}{$0-54$} & \multirow[t]{2}{*}{1} & $=1 / 32 \times 100 \%$ & \multirow[t]{2}{*}{0} & $=0 / 32 \times 100 \%$ \\
\hline & & & $=3,13 \%$ & & $=0 \%$ \\
\hline Jumlah & & 32 & $100 \%$ & 32 & $100 \%$ \\
\hline
\end{tabular}

Sumber : Data olahan hasil penelitian

Data hasil belajar ranah kognitif diatas menunjukkan bahwa tujuan pembelajaran telah berhasil dicapai dengan jumlah siswa yang menguasai materi pembelajaran secara tuntas $(\mathrm{N} \geq 75)$. Hal ini berarti bahwa penerapan model Blended Learning telah berhasil meningkatkan hasil belajar siswa pada ranah kognitif. Hasil belajar kognitif siswa dapat meningkat disebabkan karena keunggulan dari model pembelajaran Blended Learning. Siswa dapat melakukan proses pembelajaran dengan leluasa, dengan akses materi yang mudah melalui online serta mudah untuk berkomunikasi dan berdiskusi baik dengan guru maupun teman yang dilakukan dimana saja dengan media internet (Husamah, 2014). Selain kemudahan ini, pembelajaran dengan model blended learning juga dapat memberikan kesempatan kepada siswa untuk berpikir kritis sehingga berpengaruh pada hasil belajar kognitifnya (Ambar Ningsih et al., 2018).

b. Peningkatan Hasil Belajar Afektif

Keberhasilan ranah afektif terwujud apabila siswa telah mampu melakukan ranah-ranah afektif yang dituntut dalam proses pembelajaran. Hal ini dapat dilihat dari hasil observasi terkait ranah-ranah afektif siswa yang dinilai melalui pengamatan pada saat proses pembelajaran berlangsung. Siswa dikatakan telah mencapai kriteria ketuntasan belajar apabila rata-rata dari seluruh ranahnya telah memperoleh nilai baik dan sangat baik atau minimal $75 \%$.

Hasil tindakan menunjukkan bahwa telah terjadi peningkatan hasil belajar siswa pada ranah afektif antara siklus I dan siklus II. Pada siklus I dengan penerapan Model Blended Learning terdapat 26 orang dari 32 siswa atau sebesar $81,26 \%$ dari keseluruhan siswa dalam satu kelas. Dan nilai rata-rata kelas untuk ranah kognitif sebesar 15,28. Pada siklus II guru berusaha meningkatkan hasil belajar siswa dan berhasil mencapai $100 \%$ dan masuk dalam kategori baik dan sangat baik dengan nilai rata-rata kelas 16,18. Berikut ini adalah tabel untuk menyajikan peningkatan hasil belajar siswa ranah afektif antara siklus I dengan siklus II. 
Tabel 2.Hasil Belajar Afektif Siswa Siklus I dan II

\begin{tabular}{|c|c|c|c|c|}
\hline Kategori & Simbol & Nilai & Siklus I & Siklus II \\
\hline \multirow[t]{2}{*}{ Sangat Baik } & \multirow[t]{2}{*}{ A } & \multirow{2}{*}{$\begin{array}{c}16,25 \leq X \leq \\
20,00\end{array}$} & $=15 / 32 \times 100 \%$ & $=3 / 32 \times 100 \%$ \\
\hline & & & $=46,88 \%$ & $=9,38 \%$ \\
\hline \multirow[t]{2}{*}{ Baik } & \multirow[t]{2}{*}{ B } & \multirow{2}{*}{$\begin{array}{c}12,50 \leq \mathrm{X} \leq \\
16,25\end{array}$} & $=11 / 32 \times 100 \%$ & $=29 / 32 \times 100 \%$ \\
\hline & & & $=34,38 \%$ & $=90,63 \%$ \\
\hline \multirow[t]{2}{*}{ Tidak Baik } & \multirow[t]{2}{*}{$\mathrm{C}$} & \multirow[t]{2}{*}{$8,75 \leq X \leq 12,50$} & $=6 / 32 \times 100 \%$ & $=0 / 32 \times 100 \%$ \\
\hline & & & $=18,75 \%$ & $=0 \%$ \\
\hline \multirow[t]{2}{*}{ Sangat Tidak Baik } & \multirow[t]{2}{*}{$\mathrm{D}$} & \multirow[t]{2}{*}{$5,00 \leq X \leq 8,75$} & $=0 / 32 \times 100 \%$ & $=0 / 32 \times 100 \%$ \\
\hline & & & $=0 \%$ & $=0 \%$ \\
\hline \multicolumn{3}{|c|}{ Jumlah } & $100 \%$ & $100 \%$ \\
\hline
\end{tabular}

Sumber : Data olahan hasil penelitian

Data hasil belajar siswa ranah afektif di atas menunjukkan bahwa terjadi peningkatan hasil belajar siswa ranah afektif siklus I ke siklus II. Pada siklus I hasil belajar siswa dalam satu kelas sebanyak 81,26\% yang mencapai kriteria baik dan sangat baik, sedangkan pada siklus II kemampuan afektif siswa dengan hasil 100\% siswa dalam satu kelas mencapai kriteria baik dan sangat baik. Dengan demikian dapat disimpulkan bahwa penerapan model Blended Learning berhasil meningkatkan hasil belajar siswa ranah afektif siswa kelas X A Akuntansi SMK Negeri 1 Ende. Meningkatnya hasil belajar afektif ini relevan dengan penelitian yang dilakukan oleh Fidiatun et al. (2018) dimana hasil belajar siswa baik kognitif, afektif dan psikomotorik dapat ditingkatkan dengan menggunakan blended learning berbasis aplikasi Schoology.

c. Peningkatan Hasil Belajar Ranah Psikomotor

Keberhasilan ranah psikomotor terwujud apabila siswa telah mampu melakukan ranah-ranah psikomotor yang dituntut dalam proses pembelajaran. Hal ini dapat dilihat berdasarkan observasi terkait ranah-ranah psikomotor siswa yang dinilai melalui pengamatan pada saat proses pembelajaran.

Hasil tindakan menunjukkan bahwa telah terjadi peningkatan hasil belajar siswa pada ranah psikomotor antara siklus I dan siklus II. Pada siklus I dengan penerapan Model Pembelajaran Blended Learning mencapai kriteria ketercapaian sebanyak 13 siswa dari 32 siswa atau sebesar 40,62\%. Pada siklus II guru berusaha untuk meningkatkan ranah psikomotor siswa dan berhasil dengan ketercapaian 100\% dengan nilai rata-rata 14,88 . Berikut ini adalah tabel yang menyajikan peningkatan hasil belajar siswa ranah psikomotor antara siklus I dengan siklus II:

Tabel 3. Hasil Belajar Psikomotor Siswa Siklus I dan II

\begin{tabular}{|c|c|c|c|c|}
\hline Kategori & Simbol & Nilai & Siklus I & Siklus II \\
\hline Sangat Baik & A & $16,25 \leq X \leq 20,00$ & $\begin{array}{l}=2 / 32 \times 100 \% \\
=6,25 \%\end{array}$ & $\begin{array}{l}=1 / 32 \times 100 \% \\
=3,13 \%\end{array}$ \\
\hline Baik & B & $12,50 \leq X \leq 16,25$ & $=11 / 32 \times 100 \%$ & $\begin{array}{l}=31 / 32 \times \\
100 \%\end{array}$ \\
\hline Tidak Baik & C & $8,75 \leq X \leq 12,50$ & $\begin{array}{l}=34,37 \% \\
=19 / 32 \times 100 \% \\
=59,37 \%\end{array}$ & $\begin{array}{l}=96,88 \% \\
=0 / 32 \times 100 \% \\
=0 \%\end{array}$ \\
\hline Sangat Tidak Baik & $\mathrm{D}$ & $5,00 \leq X \leq 8,75$ & $\begin{array}{l}=0 / 32 \times 100 \% \\
=0 \%\end{array}$ & $\begin{array}{l}=0 / 32 \times 100 \% \\
=0 \%\end{array}$ \\
\hline \multicolumn{3}{|c|}{ Jumlah } & $100 \%$ & $100 \%$ \\
\hline
\end{tabular}

Sumber : Data olahan hasil penelitian 
186 Penerapan Model Pembelajaran Blanded Learning dalam Meningkatkan Hasil Belajar Siswa Sekolah Menengah Kejuruan - Marsel Nande, Wati Ahmad Irman

DOI : https://doi.org/10.31004/edukatif.v3i1.240

Data hasil belajar siswa ranah psikomotor diatas menunjukkan terjadi peningkatan hasil belajar siswa ranah psikomotor siklus I ke siklus II. Pada siklus I hasil belajar siswa dalam satu kelas sebanyak 40,62\% dan pada siklus II kemampuan psikomotor siswa mencapai $100 \%$ dan masuk dalam kategori baik dan sangat baik.

Dengan demikian dapat disimpulkan bahwa penerapan model pembelajaran Blended Learning berhasil meningkatkan hasil belajar ranah psikomotor siswa kelas X A Akuntansi SMK Negeri 1 Ende. Meningkatnya hasil belajar afektif ini relevan dengan penelitian yang dilakukan oleh Fidiatun et al (2018) dan penelitian yang dilakukan oleh Ningsih et al (2018) dimana hasil belajar siswa baik kognitif, afektif dan psikomotorik dapat ditingkatkan dengan menggunakan blended learning berbasis aplikasi Schoology.

Berdasarkan pembahasan diatas yang meliputi pelaksanaan tindakan, hasil tindakan, dan dukungan teori serta hasil penelitian yang ada maka dapat disimpulkan bahwa penggunaaan Model Pembelajaran Blended Learning dapat meningkatkan hasil belajar ranah kognitif, afektif dan psikomotor siswa kelas X A Akuntansi SMK Negeri 1 Ende Tahun Ajaran 2019/2020.

\section{KESIMPULAN}

Berdasarkan hasil penelitian dapat disimpulkan bahwa penerapan model pembelajaran Blended Learning dapat meningkatkan hasil belajar siswa kelas XA Akuntansi SMK Negeri 1 Ende baik dari ranah kognitif, afektif dan psikomotor. Hasil belajar siswa dari ketiga ranah meningkat dari Siklus I ke Siklus II masing-masing ranah kognitif sebesar 18,64\%, ranah afektif sebesar 58,90\% dan ranah psikomotor sebesar 27,72\%. Berdasarkan kesimpulan di atas maka dapat direkomendasikan beberapa hal sebagai berikut.

1. Guru dapat menggunakan model pembelajaran Blended Learning untuk memastikan siswa tetap belajar dengan pengawasan guru secara daring menggunakan media sosial yang familiar dengan para siswa.

2. Sekolah secara kelembagaan hendaknya memfasilitasi para guru dan siswa agar dapat melaksanakan pembelajaran kombinasi tatap muka dan daring dengan memberikan pelatihan dan menyiapkan fasilitas yang memadai.

3. Orang Tua siswa perlu memberikan dukungan fasilitas pembelajaran daring dan mendampingi anak ketika proses belajar di rumah.

\section{DAFTAR PUSTAKA}

Abdullah, W. (2018). Model Blended Learning dalam Meningkatkan Efektifitas Pembelajaran. FIKROTUNA, 7(1), 855-866. https://doi.org/10.32806/jf.v7i1.3169

Ambar Ningsih, W. S., Suana, W., \& Maharta, N. (2018). PENGARUH PENERAPAN BLENDED

LEARNING BERBASIS SCHOOLOGY TERHADAP KEMAMPUAN BERPIKIR KRITIS SISWA.

KONSTAN - JURNAL FISIKA DAN PENDIDIKAN FISIKA, 3(2), 85-93.

https://doi.org/10.20414/konstan.v3i2.16

Budiarti, L., \& Supraptono, E. (2015). Peningkatan Kemampuan Pembuatan Aplikasi Buku Besar Dengan Pendekatan Model Team Assisted Individual (Tasid). Didaktikum, 16(3). http://www.irpp.com/index.php/didaktikum/article/view/276

Dziuban, C., Hartman, J., Juge, F., Moskal, P., \& Sorg, S. (2006). Blended learning enters the mainstream. The Handbook of Blended Learning: Global Perspectives, Local Designs, 195-208.

Fidiatun, E. N., Indrawati, C. D. S., \& Ninghardjanti, P. (2018). PENERAPAN BLENDED LEARNING BERBASIS APLIKASI SCHOOLOGY SEBAGAI UPAYA UNTUK MENINGKATKAN HASIL BELAJAR ADMINISTRASI HUMAS DAN KEPROTOKOLAN. PAEDAGOGIA, $21(1), 85$. https://doi.org/10.20961/paedagogia.v21i1.18454 
187 Penerapan Model Pembelajaran Blanded Learning dalam Meningkatkan Hasil Belajar Siswa Sekolah Menengah Kejuruan - Marsel Nande, Wati Ahmad Irman

DOI : https://doi.org/10.31004/edukatif.v3i1.240

Hanum, N. S. (2013). Keefetifan e-learning sebagai media pembelajaran (studi evaluasi model pembelajaran e-learning SMK Telkom Sandhy Putra Purwokerto). Jurnal Pendidikan Vokasi, 3(1).

https://doi.org/10.21831/jpv.v3i1.1584

Hignasari, L. V., \& Supriadi, M. (2020). Pengembangan E-Learning dengan Metode Self Assessment Untuk Meningkatkan Hasil Belajar Matematika Mahasiswa Universitas Mahendradatta. Jurnal Kependidikan: Jurnal Hasil Penelitian Dan Kajian Kepustakaan Di Bidang Pendidikan, Pengajaran Dan Pembelajaran, 6(2), 206. https://doi.org/10.33394/jk.v6i2.2476

Husamah, H. (2014). Pembelajaran bauran (Blended learning). Hasil Pustaka.

Lestiyani, P. (2020). Analisis Persepsi Civitas Akademika Terhadap Konsep Merdeka Belajar Menyongsong Era Industri 5.0. Jurnal Kependidikan: Jurnal Hasil Penelitian Dan Kajian Kepustakaan Di Bidang Pendidikan, Pengajaran Dan Pembelajaran, 6(3), 365. https://doi.org/10.33394/jk.v6i3.2913

Muzakkir, M., Wibawa, R., Astutik, F., \& Muhakkikin, M. (2018). Pengembangan Perangkat Model Blended Learning untuk Meningkatkan Efektivitas Penerapan Pendidikan Jarak Jauh di SMKN 2 Gerung. Jurnal Kependidikan: Jurnal Hasil Penelitian Dan Kajian Kepustakaan Di Bidang Pendidikan, Pengajaran Dan Pembelajaran, 4(2), 173-177. https://doi.org/10.33394/jk.v4i2.1126

Prama Deswita, A. (2015). PENGARUH PERSEPSI SISWA TENTANG GAYA MENGAJAR GURU DAN MINAT BELAJAR SISWA TERHADAP HASIL BELAJAR AKUNTANSI PADA PROGRAM KEAHLIAN AKUNTANSI SISWA KELAS X DI SMKN 1 SAWAHLUNTO. Economica, 2(1), 1-10. https://doi.org/10.22202/economica.2013.v2.i1.211

Rahim, A., \& Dwiprabowo, R. (2020). PENERAPAN METODE ROLE PLAYING PADA MATA PELAJARAN PPKN DI SEKOLAH DASAR. Prima Magistra: Jurnal Ilmiah Kependidikan, 1(2), 210217. https://doi.org/10.37478/jpm.v1i2.651

Seto, S. B., Suryani, L., \& Bantas, M. G. D. (2020). ANALISIS EFIKASI DIRI DAN HASIL BELAJAR BERBASIS E-LEARNING PADA MAHASISWA PROGRAM STUDI PENDIDIKAN MATEMATIKA. Prima Magistra: Jurnal Ilmiah Kependidikan, 1(2), 147-152. https://doi.org/10.37478/jpm.v1i2.472

Siregar, B. G. (2019). TAHAP PENCATATAN TRANSAKSI DALAM SIKLUS AKUNTANSI PERUSAHAAN JASA. https://doi.org/https://doi.org/10.31227/osf.io/phv9u

Wardani, U. K. (2015). Peningkatan Minat dan Hasil Belajar Memproses Buku Besar Melalui Pembelajaran Tutor Sebaya Pada Kelas X Akuntansi 3 SMK NI Salatiga Semester Genap Tahun 2013/2014. Jurnal Pendidikan Ilmu Sosial, 25(2), 66-77. http://journals.ums.ac.id/index.php/jpis/article/view/153

Wiwiseno, Y. (2011). PENGARUH MINAT, DISIPLIN, DAN CARA BELAJAR TERHADAP HASIL BELAJAR AKUNTANSI PADA SISWA KELAS XI MAN 1 BREBES. Universitas Negeri Semarang. http://lib.unnes.ac.id/id/eprint/7126

Yazdi, M. (2012). E-learning sebagai media pembelajaran interaktif berbasis teknologi informasi. Jurnal Ilmiah Foristek, 2(1). http://jurnal.untad.ac.id/jurnal/index.php/FORISTEK/article/view/665 